\title{
Delineation of Borrelia burgdorferi Sensu Stricto, Borrelia garinii sp. nov., and Group VS461 Associated with Lyme Borreliosis
}

\author{
GUY BARANTON,${ }^{1 *}$ DANIELE POSTIC, ${ }^{1}$ ISABELLE SAINT GIRONS,${ }^{1}$ PATRICK BOERLIN, ${ }^{2}$ \\ JEAN-CLAUDE PIFFARETTI,${ }^{2}$ MARC ASSOUS, ${ }^{3}$ AND PATRICK A. D. GRIMONT ${ }^{4}$
}

Unité de Bactériologie Moléculaire et Médicale, Institut Pasteur, 75724 Paris Cedex 15, France ; Istituto Cantonale Batteriologico, 6904 Lugano, Switzerland ${ }^{2}$; Faculté de Médecine Cochin-Port-Royal, 75674 Paris Cedex 14, France ${ }^{3}$; and Unité des Entérobactéries, Institut National de la Santé et de la Recherche Médicale, Unité 199, Institut Pasteur, 75724 Paris Cedex 15, France 4

\begin{abstract}
We studied 48 Borrelia isolates that were associated with Lyme borreliosis or were isolated from ticks and identified three DNA relatedness groups by using the S1 nuclease method. The three DNA groups (genospecies) were associated with specific rRNA gene restriction patterns, protein electrophoresis patterns, and patterns of reactivity with murine monoclonal antibodies. Genospecies I corresponded to Borrelia burgdorferi sensu stricto since it contained the type strain of this species (strain ATCC 35210); this genospecies included 28 isolates from Europe and the United States. Genospecies II was named Borrelia garinii sp. nov. and included 13 isolates from Europe and Japan. Genospecies III (group VS461) included seven isolates from Europe and Japan.
\end{abstract}

The bacterial agent of Lyme borreliosis was discovered by Burgdorfer et al. in 1982 (11), and in 1984 Johnson et al. (20) described this organism as a new species of the genus Borrelia, Borrelia burgdorferi. Since then, strains have been isolated in all parts of the world from both humans and animals.

At the present time workers recognize a single Borrelia species associated with Lyme disease, although it has been shown that different strains are genomically and phenotypically heterogeneous.

The results of several studies in which workers used restriction endonuclease analysis (23), partial sequencing of rRNA (1), the polymerase chain reaction (29), plasmid profiles $(4,5,31)$, Western blotting (immunoblotting), reactivity with monoclonal antibodies (MAbs) $(6,7,35)$, and ultrastructural characteristics (18) have suggested that $B$. burgdorferi sensu lato is heterogeneous.

Researchers have performed three DNA relatedness studies which have examined $B$. burgdorferi isolates. In the first study, two American strains and one European strain were included (19). In the second study the researchers included the same three strains and seven additional American isolates $(30)$. The authors of both of these studies concluded that all of the strains belong to one species. It should be noted that only one European strain was included in these studies. In the third study 13 strains that were mostly European isolates were used, and the authors identified two genomic species (28).

Differences between European and North American isolates of B. burgdorferi have also been observed in Southern hybridization experiments (24).

Recently, we encountered strains that did not fit the previously published descriptions of genomic species (28). The purposes of this study were (i) to delineate additional genomic groups among strains received as $B$. burgdorferi, (ii) to characterize the genomic groups on the basis of rRNA gene restriction patterns, and (iii) to provide an easy means for identification by using MAbs.

Below, we propose that our strains of $B$. burgdorferi sensu lato should be split into three genospecies, two of which can

\footnotetext{
* Corresponding author.
}

be named. Genospecies I corresponds to $B$. burgdorferi sensu stricto, and genospecies II is named Borrelia garinii sp. nov. Genospecies III is referred to below as group VS461.

\section{MATERIALS AND METHODS}

Bacterial strains. The Borrelia strains that we used in this study are listed in Table 1 . They were grown in BSKII medium at $34^{\circ} \mathrm{C}(3)$.

DNA-DNA reassociation. Previously described methods for extracting and purifying DNA were used (10). DNA relatedness was determined by the $S 1$ nuclease method (12), using a previously described procedure (17). The same methods were used in a previous work (28). The temperature at which $50 \%$ of the reassociated DNA became hydrolyzable by $\mathrm{S} 1$ nuclease $\left(T_{m}\right)$ was measured $(12)$, and the differences between the $T_{m}$ of a homoduplex (in a homologous reaction) and the $T_{m}$ values of heteroduplexes (in heterologous reactions) $\left(\Delta T_{m} \mathrm{~s}\right)$ were determined in order to estimate DNA divergence.

DNA base composition. The guanine-plus-cytosine $(\mathrm{G}+\mathrm{C})$ contents of DNAs were determined from melting temperatures that were compared with the melting temperature of Escherichia coli $\mathrm{K}-12$ DNA (G+C content, $50.6 \mathrm{~mol} \%)$ and were calculated by using the equation of Owen et al. (25).

rRNA gene restriction patterns. The exact procedures which we used for restriction, transfer to nylon membranes, and hybridization with radiolabeled rRNA from $E$. coli have been described previously (15). In addition, for some strains the DNA fragments were transferred to Hybond-C extra membranes (Amersham International, Amersham, England) and hybridized with acetylaminofluorene-labeled $16+23 \mathrm{~S}$ rRNA (Eurogentec, Liège, Belgium) as described elsewhere (14).

All strains were separately digested with four enzymes (EcoRI and EcoRV from Boehringer, Mannheim, Germany, and PstI and HindIII from Appligène, Illkirch, France) by using conditions recommended by the manufacturers.

Protein electrophoresis and reactivity with MAbs. For sodium dodecyl sulfate-polyacrylamide gel electrophoresis, proteins from whole-cell lysates $(25 \mu \mathrm{g}$ of protein per lane) were subjected to $12.5 \%$ sodium dodecyl sulfate-polyacryl- 
TABLE 1. Strains used in this study

\begin{tabular}{|c|c|c|}
\hline Strain & Origin & $\begin{array}{l}\text { Geographic } \\
\text { location }\end{array}$ \\
\hline \multicolumn{3}{|l|}{$\begin{array}{l}\text { Genospecies I (B. burg- } \\
\text { dorferi sensu stricto) }\end{array}$} \\
\hline IP1 & Human $(\mathrm{CSF})^{a}$ & France \\
\hline IP2 & Human (CSF) & France \\
\hline IP3 & Human (CSF) & France \\
\hline 297 & Human (CSF) & United States \\
\hline IRS & Lodes ricinus & Switzerland \\
\hline 20006 & Lxodes ricinus & France \\
\hline 212 & Lxodes ricinus & France \\
\hline Z118 & Lxodes ricinus & Germany \\
\hline Z136 & Lxodes ricinus & Germany \\
\hline $\mathrm{B} 31^{\mathrm{T}}\left(=\operatorname{ATCC} 35210^{\mathrm{T}}\right)$ & Lxodes dammini & United States \\
\hline Charlie tick & Lxodes dammini & United States \\
\hline 27985 & Lxodes dammini & United States \\
\hline HUM3336 & Lxodes pacificus & United States \\
\hline SON328 & Lxodes pacificus & United States \\
\hline HUM115 & Lxodes pacificus & United States \\
\hline HUM7814 & Ixodes pacificus & United States \\
\hline SUN2110 & Lxodes pacificus & United States \\
\hline SON335 & Lxodes pacificus & United States \\
\hline MEN115 & Lxodes pacificus & United States \\
\hline SON188 & Lxodes pacificus & United States \\
\hline LAKE339 & Ixodes pacificus & United States \\
\hline CA5 & Ixodes pacificus & United States \\
\hline CA6 & Lxodes pacificus & United States \\
\hline 19535 & Peromyscus leucopus & United States \\
\hline 21305 & Peromyscus leucopus & United States \\
\hline 21343 & Peromyscus leucopus & United States \\
\hline 26816 & Microtus pennsylvanicus & United States \\
\hline Ip21 & Lxodes persulcatus & USSR \\
\hline \multicolumn{3}{|c|}{$\begin{array}{l}\text { Genospecies II (B. garinii } \\
\text { sp. nov.) }\end{array}$} \\
\hline $20047^{\mathrm{T}}$ & Lxodes ricinus & France \\
\hline 153 & Lxodes ricinus & France \\
\hline G25 & Ixodes ricinus & Sweden \\
\hline N34 & Ixodes ricinus & Germany \\
\hline T25 & Lxodes ricinus & Germany \\
\hline TN & Lxodes ricinus & Germany \\
\hline VS185 & Ixodes ricinus & Switzerland \\
\hline VS286 & Lxodes ricinus & Switzerland \\
\hline VS468 & Ixodes ricinus & Switzerland \\
\hline $\mathrm{PBi}$ & Human (CSF) & Germany \\
\hline $\mathrm{PBr}$ & Human (CSF) & Germany \\
\hline HP3 & Lxodes persulcatus & Japan \\
\hline IPer90 & Lxodes persulcatus & USSR \\
\hline \multirow{2}{*}{\multicolumn{3}{|c|}{$\begin{array}{l}\text { Genospecies III (group } \\
\text { VS461) }\end{array}$}} \\
\hline & & \\
\hline $\mathrm{BO} 23$ & Human (skin) & Germany \\
\hline PGau & Human (skin) & Germany \\
\hline UMO1 & Human (skin) & Sweden \\
\hline VS461 & Ixodes ricinus & Switzerland \\
\hline F1 & Lxodes ricinus & Sweden \\
\hline IPer3 & Loodes persulcatus & USSR \\
\hline I.persulcatus & Lxodes persulcatus & Japan \\
\hline
\end{tabular}

${ }^{a}$ CSF, cerebrospinal fluid.

amide gel electrophoresis as described by Laemmli (22). Gels were stained with Coomassie brilliant blue.

For Western blotting, proteins $(10 \mu \mathrm{g}$ of protein per lane) were subjected to sodium dodecyl sulfate-polyacrylamide gel electrophoresis and transferred to nitrocellulose membranes by semidry graphite blotting. The membranes were blocked and probed by using standard procedures (32). Murine MAbs H9724, H5332, H3TS, and H6831 (Symbicom, Umeå, Sweden) were used as recommended by the manu-
TABLE 2. Levels of DNA relatedness among three Borrelia genospecies

\begin{tabular}{lccc}
\hline \multirow{2}{*}{$\begin{array}{l}\text { Source of un- } \\
\text { labeled DNA }\end{array}$} & \multicolumn{3}{c}{ Relative binding ratios (\%) with the following } \\
(strain) & sources of labeled DNA: \\
\cline { 2 - 4 } & Strain & Strain & Strain \\
\hline B31 & B31 & $20047^{\mathrm{T}}$ & VS461 \\
IP1 $^{\mathrm{T}}$ & $100(0)^{a}$ & $55(8)$ & $48(9)$ \\
IP2 & 98 & ND & ND \\
IP3 & 91 & ND & ND \\
297 & 99 & ND & ND \\
IRS & 85 & ND & ND \\
20006 & 100 & ND & ND \\
Z136 & $87(3)$ & ND & ND \\
212 & 80 & ND & ND \\
Charlie tick & 88 & $67(8)$ & 50 \\
21305 & 82 & ND & ND \\
HUM7814 & 84 & 55 & ND \\
20047 & 80 & 49 & ND \\
G25 & $51(10)$ & $100(0)$ & $65(7)$ \\
N34 & $57(10)$ & $87(1)$ & ND \\
153 & $54(10)$ & $80(2)$ & ND \\
VS185 & ND & $76(2)$ & ND \\
VS286 & ND & 100 & 61 \\
VS468 & ND & 100 & 53 \\
PBi & ND & $83(3)$ & 64 \\
PBr & $55(9)$ & $85(1)$ & $74(9)$ \\
T25 & ND & $88(3)$ & 58 \\
HP3 & ND & $82(1)$ & $67(9)$ \\
TN & ND & $92(1)$ & 66 \\
IPer90 & ND & $90(3)$ & 61 \\
VS461 & ND & 87 & ND \\
BO23 & 51 & $62(7)$ & $100(0)$ \\
PGau & ND & $54(7)$ & $100(2)$ \\
I.persulcatus & ND & $73(8)$ & 87 \\
IPer3 & ND & $71(8)$ & 100 \\
F1 & ND & 68 & 100 \\
UM01 & ND & 68 & 98 \\
& ND & 69 & 100 \\
\hline
\end{tabular}

${ }^{a}$ Relative binding ratios were determined at $60^{\circ} \mathrm{C}$. The levels of reassociation in homologous reactions ranged from 74 to $103 \%$ before normalization. The S1 nuclease-resistant core (in the tube containing only denatured labeled DNA) showed an average of $7 \%$ reassociation; these control values were subtracted before normalization. The values in parentheses are $\Delta T_{m}$ values (in degrees Celsius), rounded off to the nearest $0.5^{\circ} \mathrm{C}$.

${ }_{b} \mathrm{ND}$, not done.

facturer (6). Murine MAb D6 directed against a 12-kDa protein was kindly supplied by Péter and Bretz (27).

\section{RESULTS AND DISCUSSION}

DNA relatedness. The levels of DNA relatedness for 32 Borrelia strains are shown in Table 2. According to the criteria that are currently used to delineate genomic species $(9,16,33)$, the differences observed in DNA relatedness values and especially in $\Delta T_{m}$ values are great enough to distinguish three genomic species (B. burgdorferi sensu stricto, $B$. garinii sp. nov., and group VS461). Within each genomic species, the levels of DNA relatedness to the reference strain ranged from 76 to $100 \%$, and the $\Delta T_{m}$ values were less than $3^{\circ} \mathrm{C}$. Between genomic species, the levels of DNA relatedness to the heterologous reference strains ranged from 46 to $74 \%$, and the $\Delta T_{m}$ values were more than $7^{\circ} \mathrm{C}$.

DNA base composition. The $\mathrm{G}+\mathrm{C}$ contents of the DNAs ranged from $27 \mathrm{~mol} \%$ (strains $20047^{\mathrm{T}}$ [ $\mathrm{T}=$ type strain], VS468, N34, VS461, and I.persulcatus) to $28 \mathrm{~mol} \%$ (strains $\mathrm{B} 31^{\mathrm{T}}, \mathrm{G} 25$, and $\mathrm{PBi}$ ), and the experimental variation was 1 to 


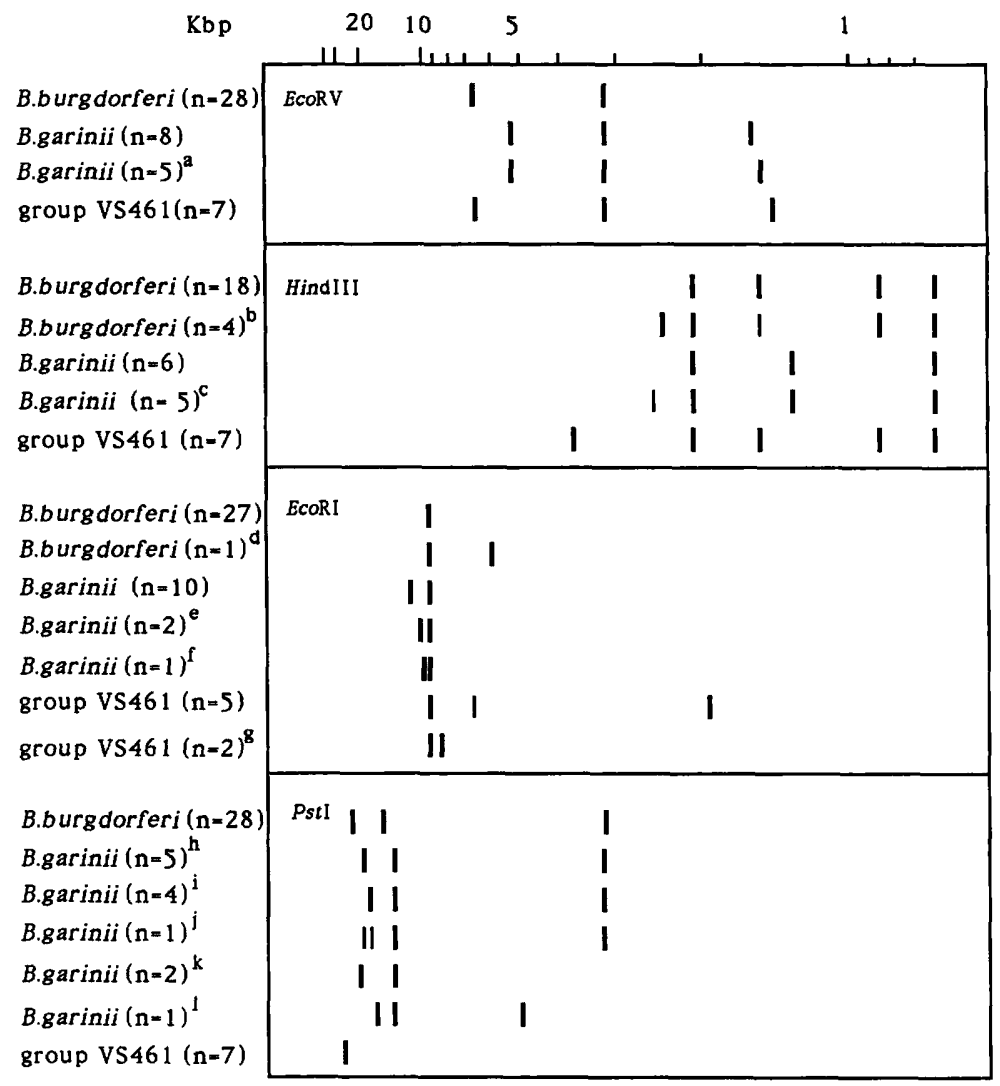

FIG. 1. Normalized graph showing the migration patterns of rRNA gene restriction fragments after cleavage by EcoRV, HindIII, EcoRI, and $P s t \mathrm{I}$ and hybridization with labeled $E$. coli $16+23 \mathrm{~S}$ rRNA. The normalized migration values were obtained from mean fragment sizes by using the following experimental formula which relates migration $(M)$ (in millimeters) to size $(S)$ (in base pairs): $M=299,820 /(S+1,692)+$ 3. Thick and thin lines indicate strongly and weakly labeled fragments, respectively. The superscripts indicate the strains used, as follows: a, strains G25, N34, VS468, PBi, and TN; b, strains 297, 21305, HUM115, and HUM7814; c, strains 20047 ${ }^{\mathrm{T}}$, 153, VS468, TN, and IPer90; d, strain IRS; e, strains VS468 and TN; f, strain IPer90; g, strains BO23 and I.persulcatus; h, strains G25, N34, 153, VS286, and PBi; i, strains 20047 ${ }^{\mathrm{T}}$, VS185, T25, and HP3; j, strain PBr; k, strains VS468 and TN; and l, strain IPer90.

2 mol\%. We found no significant differences among the strains tested. The $\mathrm{G}+\mathrm{C}$ contents given by Johnson et al. (20) ranged from 27.3 to $30.5 \mathrm{~mol} \%$.

rRNA gene restriction patterns. Labeled $E$. coli $16+23 S$ rRNA was used as a probe to visualize the rRNA gene restriction patterns of 48 Borrelia strains. Figure 1 shows a normalized representation of the patterns exhibited by 48 isolates. The fragment sizes indicated on Fig. 1 are average sizes. The standard deviations for the averages were 0.1 to $1.3 \%$ for sizes ranging from 1 to $7.5 \mathrm{kbp}$ and 2 to $4 \%$ for sizes larger than $7.5 \mathrm{kbp}$. Three major patterns were found, depending on the restriction enzyme used (Pst I, HindIII, $E c o \mathrm{RV}$, or $E c o \mathrm{RI})$. Each pattern corresponded to a genomic species.

Figure 2 shows a typical membrane exhibiting EcoRV rRNA gene restriction patterns. All of the $B$. burgdorferi sensu stricto strains produced the same pattern, and all of the group VS461 strains produced the same pattern; 5 of the 13 strains belonging to $B$. garinii sp. nov. had a minor difference in size of the smallest fragment.

Of 22 strains belonging to $B$. burgdorferi sensu stricto, 18 produced the same HindIII rRNA pattern (Fig. 1). An additional fragment $(2.5 \mathrm{~kb})$ was present in the patterns of the four remaining strains. Six strains of $B$. garinii sp. nov. produced the same pattern. An additional fragment $(2.6 \mathrm{~kb})$ was present in the patterns of five other strains. All of the strains belonging to group VS461 produced the same pattern.

With EcoRI, 27 of $28 \mathrm{~B}$. burgdorferi sensu stricto strains produced the same pattern (Fig. 1), 10 of 13 B. garinii sp. nov. strains produced the same pattern, and the patterns of 5 of 7 group VS461 strains were identical.

With Pst I, the 28 strains of $B$. burgdorferi sensu stricto produced the same pattern, and all 7 group VS461 strains produced the same pattern; greater heterogeneity was observed in $B$. garinii sp. nov.

The strains which produced different patterns could represent subtypes within each genospecies.

With EcoRI, EcoRV, and HindIII, one or two fragments were common to the three genospecies $(9.5,3.2$, and 2.1 and $0.6 \mathrm{~kb}$, respectively). These fragments were not observed in other species of Borrelia (B. hermsii, B. parkeri, and $B$. turicatae) (28).

rRNA gene restriction patterns could be used as a way to identify Borrelia isolates at the genospecies level. We recommend using EcoRV and HindIII, two enzymes which gave more reliable results for species identification than the other enzymes tested.

Protein patterns. Although there was a great deal of heterogeneity in the protein patterns, three groups based on several major proteins were identified (Table 3 ). The strains 


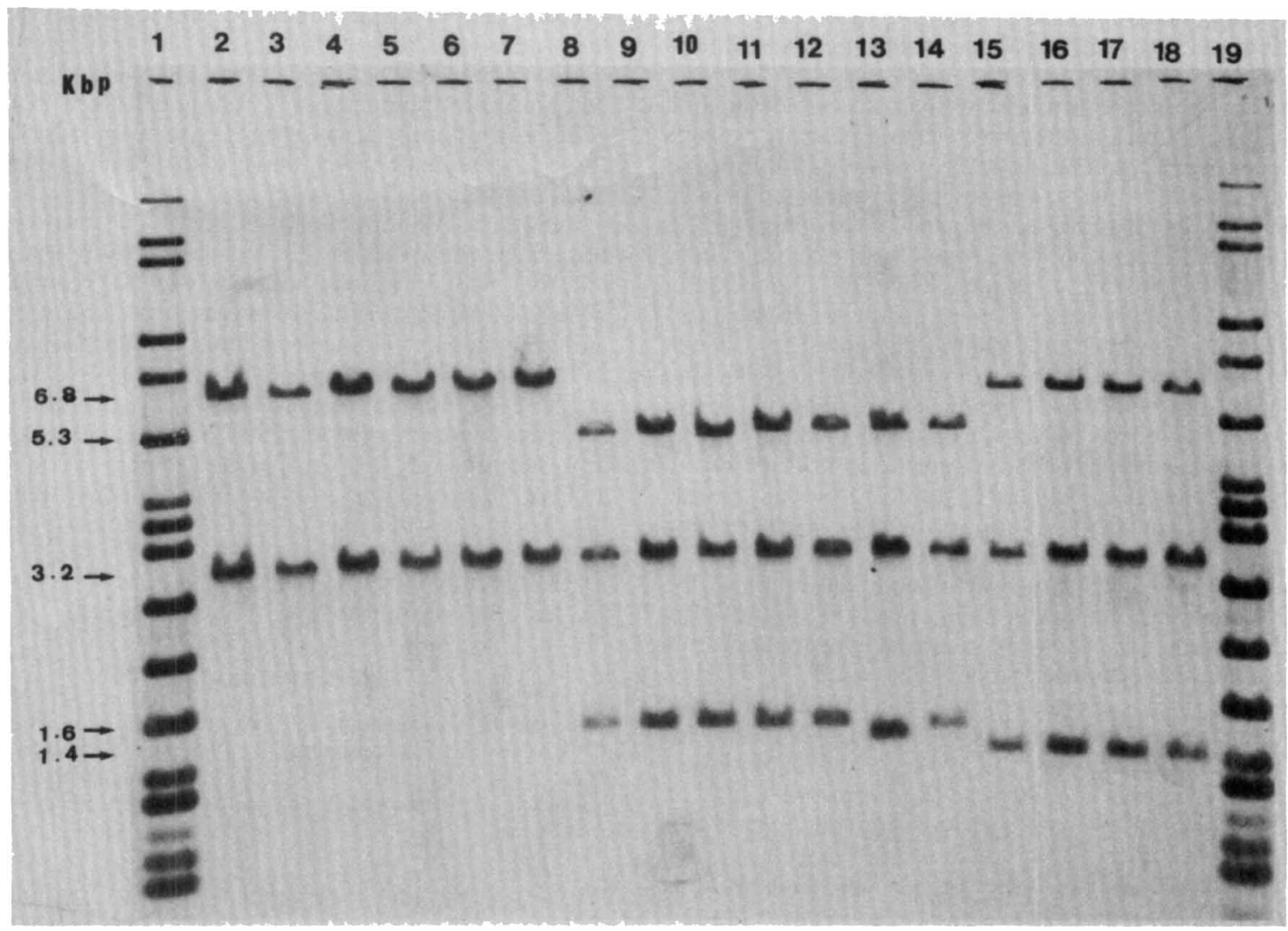

FIG. 2. rRNA gene restriction patterns after cleavage by EcoRV. $16+23 S$ RNA from $E$. coli was labeled with acetylaminofluorene. Immunodetection of rRNA-rDNA duplexes was performed by an enzyme-linked antibody reaction. Lanes 1 and 19 contained molecular weight standard Raoul 1 (Appligène). Lanes 2 to 7 contained $B$. burgdorferi sensu stricto strains B31 ${ }^{\mathrm{T}}, 212$, LAKE339, SON328, 19535, and 21305 , respectively. Lanes 8 to 14 contained $B$. garinii sp. nov. strains $20047^{\mathrm{T}}$, T25, HP3, IPer90, VS286, VS468, and PBr, respectively. Lanes 15 to 18 contained group VS461 strains VS461, PGau, I.persulcatus, and BO23, respectively.

in the first group produced two major protein bands corresponding to proteins OspA and OspB at 31 and $34 \mathrm{kDa}$, respectively. In the second group there was a single predominant protein (protein OspA at $33 \mathrm{kDa}$ ). In the third group, two major protein bands were located at 32 and $35 \mathrm{kDa}$. These differences have been described previously by Adam et al. (1). Each protein pattern group corresponded to a genospecies. Other authors have identified four groups on the basis of the electrophoretic mobilities of proteins OspA and OspB (27). The fourth group identified by these authors contained only one strain, a strain that was not included in our study.

Reactivity with MAbs. All of the strains were reactive with MAb H9724, which is genus specific. Reactivities with
MAbs H5332 and H3TS directed against protein OspA, MAb H6831 directed against protein OspB, and MAb D6 directed against a $12-\mathrm{kDa}$ protein separated $B$. burgdorferi sensu stricto and $B$. garinii sp. nov. (Table 3). Reactivity with MAb H3TS allowed identification of $B$. burgdorferi sensu stricto, and reactivity with MAb D6 allowed identification of $B$. garinii sp. nov. according to results obtained with isolates from Switzerland $(26,27)$. Group VS461 strains did not react with any MAb. These results explain the previously described heterogeneity of MAb reactivity observed with European isolates of $B$. burgdorferi sensu lato (35). Our results showed that the heterogeneity observed among American and European isolates in reactivity with MAbs is in fact supported by genetic differences. All 19 American strains

TABLE 3. Molecular weights of major outer membrane proteins and MAb reactivities

\begin{tabular}{|c|c|c|c|c|c|c|c|c|}
\hline \multirow[b]{2}{*}{ Taxon } & \multirow[b]{2}{*}{$\begin{array}{l}\text { No. of } \\
\text { strains }\end{array}$} & \multicolumn{2}{|c|}{ Mol wt $\left(10^{3}\right)^{a}$} & \multicolumn{5}{|c|}{ Reactivity with: } \\
\hline & & OspA & OspB & $\begin{array}{c}\text { MAb } \\
\text { H9724 } \\
\text { (flagellin) }\end{array}$ & $\begin{array}{c}\text { MAb } \\
\text { H5332 } \\
(\text { OspA) }\end{array}$ & $\begin{array}{c}\text { MAb } \\
\text { H3TS } \\
\text { (OspA) }\end{array}$ & $\begin{array}{c}\text { MAb } \\
\text { H6831 } \\
(\text { OspB) }\end{array}$ & $\begin{array}{c}\text { MAb D6 } \\
\text { (12-kDa protein) }\end{array}$ \\
\hline B. burgdorferi sensu stricto & 28 & 31 & 34 & + & + & + & + or $-^{b}$ & - \\
\hline$B$. garinii sp. nov. & 13 & 33 & & + & - or $+^{c}$ & - & - & + \\
\hline Group VS461 & 7 & 32 & 35 & + & - & - & - & - \\
\hline
\end{tabular}

${ }^{a}$ Molecular weight as determined by sodium dodecyl sulfate-polyacrylamide gel electrophoresis.

${ }^{b}$ Strains 297, 20006, Charlie tick, 21343, 19535, and SON2110 were negative.

$c$ Strains $20047^{\mathrm{T}}, \mathrm{PBr}, \mathrm{TN}$, and $\mathrm{HP3}$ were positive. 
studied (including strain $\mathrm{B} 31^{\mathrm{T}}$ ) belonged to $B$. burgdorferi sensu stricto, whereas the European strains were distributed among the three genospecies.

Comparison with other studies. In this study we delineated three genomic species among 48 strains. These organisms were characterized by specific rRNA gene restriction patterns. A total of 20 of the strains included in this study have been studied by using multilocus enzyme electrophoresis (8). Clustering of the electrophoretic types by the average linkage method revealed three primary clusters. Each cluster corresponded to a genospecies; eight strains of $B$. burgdorferi sensu stricto belonged to division I of Boerlin et al., eight strains of $B$. garinii sp. nov. belonged to division III, and four strains of group VS461 belonged to division II (8). Furthermore, this analysis was based upon 11 different loci coding for housekeeping enzymes and thus not subject to plasmid variation. We concluded that the multilocus enzyme electrophoresis data strongly support the DNA hybridization results.

It should be noted that a recently described method (the arbitrarily primed polymerase chain reaction method) revealed three clusters, each of which corresponded to a genospecies described in this paper (34).

Two of the three genomic species can be differentiated easily. It has been shown previously that these two species are not related to $B$. hermsii, $B$. parkeri, and $B$. turicatae (28). Genospecies I has a valid name (B. burgdorferi), and an emended description of this species is given below. For genospecies II we propose the name $B$. garinii sp. nov.; this taxon is described formally below. At the present time genospecies III remains group VS461.

Emended description of Borrelia burgdorferi sensu stricto. Morphology as described for the genus by Kelly (21). Cultural properties as described by Johnson et al. (20).

The rRNA gene restriction patterns after digestion by EcoRV contain two fragments (6.8 and $3.2 \mathrm{~kb})$.

The rRNA gene restriction patterns after digestion by HindIII contain four fragments $(2.1,1.5,0.8$, and $0.6 \mathrm{~kb})$; some strains have an additional fragment at $2.4 \mathrm{~kb}$.

All strains of this species react in Western blots with MAb H3TS directed against protein OspA. They also react with MAb H5332, which is directed against another epitope of protein OspA. The reactivity with MAb $\mathrm{H} 6831$ directed against protein OspB is variable (22 of 28 strains are reactive). No reactivity occurs with MAb D6.

$B$. burgdorferi sensu stricto has been isolated from humans (especially from cerebrospinal fluid), ticks, and rodents in Europe and the United States.

The $\mathrm{G}+\mathrm{C}$ content of the DNA is 27 to $30 \mathrm{~mol} \%$ (20).

The type strain is strain B31 (= ATCC 35210).

Description of the type strain. Strain ATCC $35210^{\mathrm{T}}$ was isolated from an Lxodes dammini tick (11). The type strain has all of the characteristics described above for the species.

After digestion by HindIII, the rRNA gene restriction pattern contains four fragments $(2.1,1.5,0.8$, and $0.6 \mathrm{~kb})$.

Reacts with MAb H6831.

The $\mathrm{G}+\mathrm{C}$ content of the DNA is $28 \mathrm{~mol} \%$ (this study) or 29 to $30 \mathrm{~mol} \%$ (20).

Description of Borrelia garinii sp. nov. Borrelia garinii ( $\mathrm{ga}^{\prime}$ ri. ni.i. M.L. gen. n. garinii, in honor of Charles Garin, a French physician who in 1922 described neurological and cutaneous symptoms which occurred in a patient after a tick bite and suspected that a spirochete was the etiological agent [13]). Also called Borrelia group 20047 in previous study (28) and genospecies II in this study.

Morphology as described previously for the genus (21).
Cultural properties as described previously for $B$. burgdorferi sensu lato (20).

rRNA gene restriction patterns after digestion by EcoRV contain three fragments $(5.3,3.2$, and 1.6 or $1.5 \mathrm{~kb})$. rRNA gene restriction patterns after digestion by HindIII contain three fragments $(2.1,1.3$, and $0.6 \mathrm{~kb})$. Some strains produce an additional weak fragment at $2.5 \mathrm{~kb}$.

Reacts in Western blots with MAb D6. No reactivity is observed with MAb H3TS. Reactivity with MAb H5332 is variable ( 4 of 13 strains are positive). No reactivity occurs with MAb H6831. B. garinii has been isolated from humans and ticks in Europe and Japan but has not been isolated yet in the United States.

The $\mathrm{G}+\mathrm{C}$ content of the DNA is 27 to $28 \mathrm{~mol} \%$.

The type strain is strain 20047 (= CIP 103362).

Description of the type strain. Strain $20047^{\mathrm{T}}$ (= CIP $103362^{\mathrm{T}}$ ) was isolated from an Lxodes ricinus tick in France (3). The type strain has all of the characteristics described above for the species.

Reacts with MAb H5332.

The $\mathrm{G}+\mathrm{C}$ content of the DNA is $28 \mathrm{~mol} \%$.

\section{ACKNOWLEDGMENTS}

We thank R. Ackerman, J. F. Anderson, B. Bancillon, M. Janda, C. Kodner, E. J. Korenberg, R. Lane, T. Masuzawa, V. PreacMursic, A. Vogt, and B. Wilske for supplying strains; O. Péter for supplying strains and MAb D6; and I. Old for critical reading of the manuscript.

\section{ADDENDUM}

Since this paper was submitted, Marconi and Garon (J. Bacteriol. 174:241-244, 1992) have reported data for $B$. burgdorferi $16 \mathrm{~S}$ rRNA sequences which support the separation of $B$. garinii from $B$. burgdorferi sensu stricto.

\section{REFERENCES}

1. Adam, T., G. S. Gassmann, C. Rasiah, and U. B. Göbel. 1991. Phenotypic and genotypic analysis of Borrelia burgdorferi isolates from various sources. Infect. Immun. 59:2579-2585.

2. Anderson, J. F., J. M. Doby, A. Couatarmanac'h, F. W. Hyde, and R. C. Johnson. 1986. Différences antigéniques entre des souches de Borrelia burgdorferi isolées d'Lxodes ricinus en Bretagne. Med. Mal. Infect. 16:171-175.

3. Barbour, A. G. 1984. Isolation and cultivation of Lyme disease spirochetes. Yale J. Biol. Med. 57:521-525.

4. Barbour, A. G. 1988. Plasmid analysis of Borrelia burgdorferi, the Lyme disease agent. J. Clin. Microbiol. 26:475-478.

5. Barbour, A. G. 1989. I. Classification of Borrelia burgdorferi on the basis of plasmid profiles, p. 1-7. In G. Stanek, W. Kristoferitsch, M. Pletschette, A. G. Barbour, and H. Flamm (ed.), Lyme borreliosis II. Gustav Fischer Verlag, Stuttgart, Germany.

6. Barbour, A. G., R. A. Heiland, and T. R. Howe. 1985. Heterogeneity of major proteins in Lyme disease borreliae: a molecular analysis of North American and European isolates. J. Infect. Dis. 152:478-484.

7. Bissett, M. L., and W. Hill. 1987. Characterization of Borrelia burgdorferi strains isolated from Ixodes pacificus ticks in California. J. Clin. Microbiol. 25:2296-2301.

8. Boerlin, P., O. Péter, A. G. Bretz, D. Postic, G. Baranton, and J. C. Piffaretti. 1992. Population genetic analysis of Borrelia burgdorferi isolates by multilocus enzyme electrophoresis. Infect. Immun. 60:1677-1683.

9. Brenner, D. J. 1978. Characterization and clinical identification of Enterobacteriaceae by DNA hybridization. Prog. Clin. Pathol. 7:71-117.

10. Brenner, D. J., A. C. McWhorter, J. K. Leete Knudson, and A. G. Steigerwalt. 1982. Escherichia vulneris: a new species of 
Enterobacteriaceae associated with human wounds. J. Clin. Microbiol. 15:1133-1140.

11. Burgdorfer, W., A. G. Barbour, S. F. Hayes, J. L. Benach, E. Grunwaldt, and J. P. Davis. 1982. Lyme disease-a tick-borne spirochetosis? Science 216:1317-1319.

12. Crosa, J. H., D. J. Brenner, and S. Falkow. 1973. Use of a single-strand-specific nuclease for analysis of bacterial and plasmid deoxyribonucleic acid homo- and heteroduplexes. $\mathrm{J}$. Bacteriol. 115:904-911.

13. Garin, C., and R. Bujadoux. 1922. Paralysie par les tiques. J. Méd. Lyon 71:765-767.

14. Grimont, F., D. Chevrier, P. A. D. Grimont, M. Lefevre, and J. L. Guesdon. 1989. Acetylaminofluorene-labelled ribosomal RNA for use in molecular epidemiology and taxonomy. Res. Microbiol. 140:447-454.

15. Grimont, F., and P. A. D. Grimont. 1986. Ribosomal ribonucleic acid gene restriction patterns as potential taxonomic tools. Ann. Inst. Pasteur/Microbiol. (Paris) 137B:165-175.

16. Grimont, P. A. D. 1988. Use of DNA reassociation in bacterial classification. Can. J. Microbiol. 34:541-546.

17. Grimont, P. A. D., M. Y. Popoff, F. Grimont, C. Coynault, and M. Lemelin. 1980. Reproducibility and correlation study of three deoxyribonucleic acid hybridization procedures. Curr. Microbiol. 4:325-330.

18. Hovind-Hougen, K., E. Asbrink, G. Stiernstedt, A. C. Steere, and A. Hovmark. 1986. Ultrastructural differences among spirochetes isolated from patients with Lyme disease and related disorders, and from Lxodes ricinus. Zentralbl. Bakteriol. Parasitenkd. Infektionskr. Hyg. Abt. 1 Orig. Reihe A 263:103-111.

19. Hyde, F. W., and R. C. Johnson. 1984. Genetic relationship of Lyme disease spirochetes to Borrelia, Treponema, and Leptospira spp. J. Clin. Microbiol. 20:151-154.

20. Johnson, R. C., G. P. Schmid, F. W. Hyde, A. G. Steigerwalt and D. J. Brenner. 1984. Borrelia burgdorferi sp. nov.: etiological agent of Lyme disease. Int. J. Syst. Bacteriol. 34:496-497.

21. Kelly, R. T. 1984. Borrelia, p. 57-62. In N. R. Krieg and J. G. Holt (ed.), Bergey's manual of systematic bacteriology, vol. 1. The Williams \& Wilkins Co., Baltimore.

22. Laemmli, U. K. 1970. Cleavage of structural proteins during the assembly of the head of bacteriophage T4. Nature (London) 277:680-685.

23. LeFebvre, R. B., R. S. Lane, G. C. Perng, J. A. Brown, and R. C. Johnson. 1990. DNA and protein analyses of tick-derived isolates of Borrelia burgdorferi from California. J. Clin. Microbiol. 28:700-707.
24. LeFebvre, R. B., G. C. Perng, and R. C. Johnson. 1989. Characterization of Borrelia burgdorferi isolates by restriction endonuclease analysis and DNA hybridization. J. Clin. Microbiol. 27:636-639.

25. Owen, R. J., L. R. Hill, and S. P. Lapage. 1969. Determination of DNA base compositions from melting profiles in dilute buffers. Biopolymers 7:503-516.

26. Péter, O. Personal communication.

27. Péter, O., and A. G. Bretz. Polymorphism of outer surface proteins of Borrelia burgdorferi as a tool for the classification. Zentralbl. Bakteriol. Parasitenkd. Infektionskr. Hyg. Abt. 1 Orig., in press.

28. Postic, D., C. Edlinger, C. Richaud, F. Grimont, Y. Dufresne, P. Perolat, G. Baranton, and P. A. D. Grimont. 1990. Two genomic species in Borrelia burgdorferi. Res. Microbiol. 141:465-475.

29. Rosa, P. A., D. Hogan, and T. G. Schwan. 1991. Polymerase chain reaction analyses identify two distinct classes of Borrelia burgdorferi. J. Clin. Microbiol. 29:524-532.

30. Schmid, G. P., A. G. Steigerwalt, S. E. Johnson, A. G. Barbour, A. C. Steere, I. M. Robinson, and D. J. Brenner. 1984. DNA characterization of the spirochete that causes Lyme disease. J. Clin. Microbiol. 20:155-158.

31. Stålhammar-Carlemalm, M., E. Jenny, L. Gern, A. Aeschlimann, and J. Meyer. 1990. Plasmid analysis and restriction fragment length polymorphisms of chromosomal DNA allow a distinction between Borrelia burgdorferi strains. Zentralbl. Bakteriol. Parasitenkd. Infektionskr. Hyg. Abt. 1 Orig. 274:28-39.

32. Towbin, H., T. Staehelin, and J. Gordon. 1979. Electrophoretic transfer of proteins from polyacrylamide gels to nitrocellulose sheets: procedure and some applications. Proc. Natl. Acad. Sci. USA 76:4350-4354.

33. Wayne, L. G., D. J. Brenner, R. R. Colwell, P. A. D. Grimont, O. Kandler, M. I. Krichevsky, L. H. Moore, W. E. C. Moore, R. G. E. Murray, E. Stackebrandt, M. P. Starr, and H. G. Trüper. 1987. Report of the Ad Hoc Committee on Reconciliation of Approaches to Bacterial Systematics. Int. J. Syst. Bacteriol. 37:463-464.

34. Welsh, J., C. Pretzman, D. Postic, I. Saint Girons, G. Baranton, and M. McClelland. 1992. Genomic fingerprinting by arbitrarily primed polymerase chain reaction resolves Borrelia burgdorferi into three distinct phyletic groups. Int. J. Syst. Bacteriol. 42:370-377.

35. Wilske, B., V. Preac-Mursic, G. Schierz, R. Kuhbeck, A. G. Barbour, and M. Kramer. 1988. Antigenic variability of Borrelia burgdorferi. Ann. N.Y. Acad. Sci. 539:126-143. 